\title{
Distribution of Recent ostracods in inland waters of Sicily (Southern Italy)
}

\author{
Valentina PIERI, Koen MARTENS ${ }^{1)}$, Luigi NASELLI-FLORES ${ }^{2)}$, Federico MARRONE ${ }^{2)}$ and Giampaolo ROSSETTI* \\ Department of Environmental Sciences, University of Parma, Parco Area delle Scienze 33A, 43100 Parma, Italy \\ ${ }^{1)}$ Royal Belgian Institute of Natural Sciences, Freshwater Biology, Vautierstraat 29, 1000 Brussels, Belgium \\ ${ }^{2)}$ Department of Botanical Sciences, University of Palermo, Via Archirafi 38, 90123 Palermo, Italy \\ *e-mail corresponding author: giampaolo.rossetti@unipr.it
}

\begin{abstract}
From 2003 to 2005, freshwater ostracods were sampled in 67 water bodies of mainland Sicily (Provinces of Agrigento, Caltanisetta, Catania, Enna, Palermo, Messina, Ragusa, Siracusa and Trapani) located from sea level up to $1300 \mathrm{~m}$ a.s.l. This survey took into account streams, springs, wells, but especially temporary and ephemeral habitats (e.g., flooded meadows, temporary ponds). The aim of this research was to give the first comprehensive picture of the regional ostracod fauna and establish relationships between the distribution of ostracod species and some habitat features. Altogether, 21 ostracod taxa belonging to five families (Candonidae, Ilyocyprididae, Cyprididae, Notodromadidae, and Limnocytheridae) were identified. A maximum of four species was found in a single sample. The most frequent species was Heterocypris incongruens, followed by Eucypris virens. The following ten taxa have been found only once: Candona lindneri, Ilyocypris decipiens, Notodromas persica, Trajancypris clavata, Herpetocypris brevicaudata, Heterocypris salina, Cypridopsis $c f$. elongata, Cypridopsis vidua, Potamocypris $c f$. villosa, and Limnocythere inopinata. The faunal assemblage of Sicily is compared with the known ostracod distribution in some Mediterranean areas.
\end{abstract}

Key words: Sicily, freshwater ostracods, taxonomy, distribution, biogeography

\section{INTRODUCTION}

With a surface of about $25,700 \mathrm{~km}^{2}$, Sicily, located in the middle of the Mediterranean Sea, is the largest island of the basin (Fig. 1). Due to its geographical position, it is considered a natural transition zone for west-palaearctic freshwater taxa with different chorological gravitation (Naselli-Flores et al. 1998). Complex orography of Sicily accounts for the presence of different bio-climatic belts (Brullo et al. 1996); nevertheless, its insularity and climate, characterized by long dry summers and short rainy winters, generally imply the lack of a well-developed permanent surface hydrographic network. For this reason, ephemeral and temporary habitats are the most common and representative types of superficial waters (Marrone et al. 2006).
The present study forms part of a larger project aiming at assessing the diversity of the crustacean fauna of inland waters of Sicily (Marrone 2003; Marrone \& Naselli-Flores 2004, 2005). The specific objectives of this research are to compare the results with previously published data, to give the first comprehensive picture of the regional ostracod fauna, and to identify possible relationships between habitat features and distribution of ostracod species. The collected data will also be used for updating the Italian ostracod checklist (Ghetti \& McKenzie 1981), which is presently under complete revision (Rossetti et al. 2004). A preliminary comparison with other ostracod faunas within the Mediterranean basin is offered.

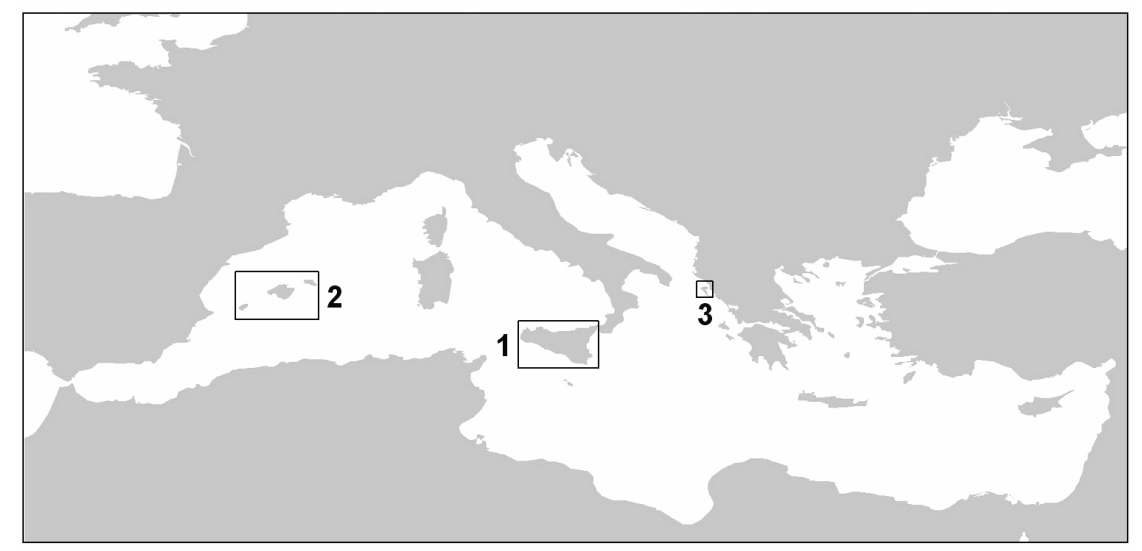

Fig. 1. Map showing the Mediterranean basin. The locations of Sicily (1), Balearic Islands (2) and Corfu (3) are indicated. 


\section{MATERIALS AND METHODS}

The study was carried out in 67 water bodies (natural or artificial, permanent or temporary, lentic or lotic) which are representative of the diverse range of freshwater habitats of Sicily (ponds, lakes, wells, flooded meadows, streams, springs, etc.) (Tab. 1). Sampling was performed from November 2003 to May 2005, and each site was visited once. The studied water bodies were generally located in sparsely populated areas and range from 3 to $1300 \mathrm{~m}$ a.s.l.

For each site, geographical coordinates were obtained with a GPS receiver (Magellan 310) and habitat features (size, water depth, presence of vegetation, lithology, etc.) were recorded. In most of the sampling sites, water temperature, $\mathrm{pH}$ and conductivity were also measured in situ using a multiprobe HI 991300 or YSI 556 MPS, respectively in shallow or deep waters.

Ostracods were collected with a handnet. Living specimens were sorted in the laboratory under a binocular microscope and then fixed in $90 \%$ ethanol. Only material allowing unambiguous identification (i.e., adults and late larval stages) was taken into account, although in few cases (Cypridopsis cf. elongata, Potamocypris cf. villosa, and Eucypris cf. virens, all found in a single sample) the specific allocation remained uncertain due to either damaged or isolated specimens. Both soft parts (dissected in glycerine and stored in sealed slides) and valves (stored dry in micropal slides) were checked for taxonomic identification following Meisch (1984, 2000) and González Mozo et al. (1996). For problematic specimens, valves were also examined by SEM using a Philips XL-30 microscope. All the collected material is deposited in the ostracod collection of the Department of Environmental Sciences, University of Parma.

\section{RESULTS}

Water conductivity showed considerable variability among sites, ranging from a minimum of $50 \mu \mathrm{S} \mathrm{cm}^{-1}$ in ME04 to a maximun $30.5 \mathrm{mS} \mathrm{cm}^{-1}$ in CL01 (Fig. 2). Nevertheless, most of the water bodies ( $\mathrm{ca} 77 \%$ ) had values below $1000 \mu \mathrm{S} \mathrm{cm} \mathrm{cm}^{-1}$. Lower conductivity waters $\left(<700 \mu \mathrm{S} \mathrm{cm}^{-1}\right)$ were mostly associated with siliceous rocks. The highest values were usually found in small ponds subjected to intense evaporation and/or affected by salt sea spray. Alkaline pHs were overwhelmingly dominant (Fig. 2), due to the prevalence of basic soils in the study area (Tab. 1) and especially to high rates of primary production in shallow waters.

In total, 21 ostracod taxa belonging to five families (Candonidae, Ilyocyprididae, Cyprididae, Notodromadidae, and Limnocytheridae) were identified (Tab. 2 ). The mean number of taxa per site (excluding immature specimens) was 1.31. A maximum of four species (Eucypris virens, Potamocypris arcuata, Trajancypris clavata and Heterocypris incongruens) was found in a temporary pond (TP04), the only site characterised by marl soil. Three species have been recorded in four sites (CL03, ME04, TP11, and TP10). In three samples (PA27, CL04 and SR03) only larval stages were present. The remaining 59 sites contained one or two ostracod species (Tab. 2); unidentified juveniles were found in 18 additional samples. The most frequent species, Heterocypris incongruens (24 records) and Eucypris virens (21 records), are typical of ephemeral and intermittent waters. In particular, $H$. incongruens was exclusively recorded in temporary ponds, most of which were characterized by carbonatic soils and high water conductivity; in 16 sites it was the only species found. Other species that were relatively frequent were Cyclocypris ovum (8 records) and Sarscypridopsis aculeata (6); Potamocypris arcuata and Tonnacypris lutaria were each found 4 times, and Cypria ophthalmica and Ilyocypris gibba were found 3 times.
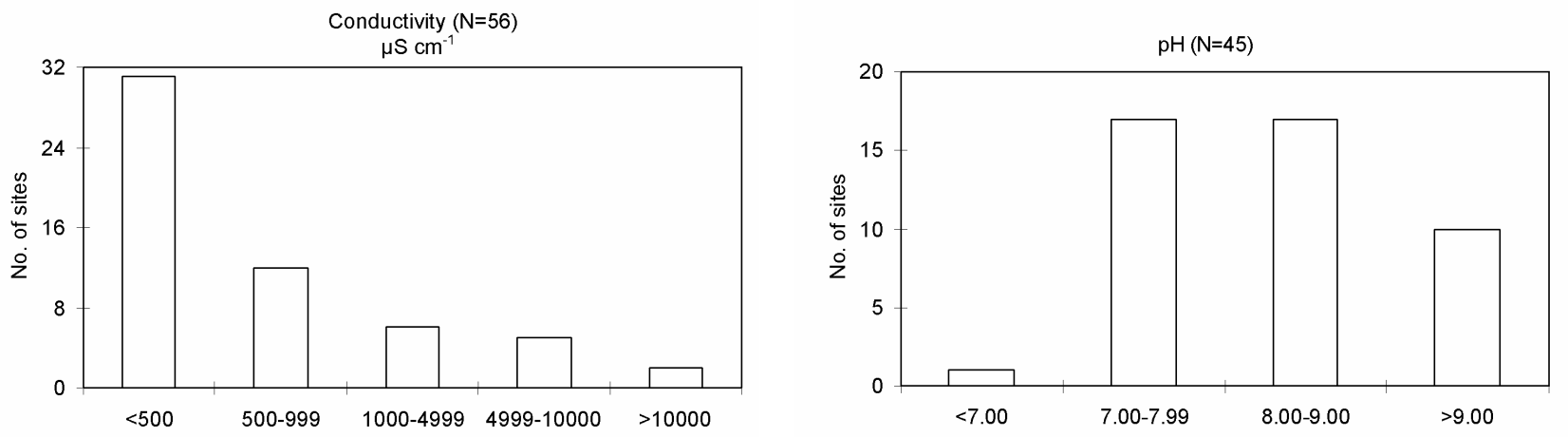

Fig. 2. Histograms showing the distribution of sampled sites by water conductivity and $\mathrm{pH}$ intervals. 


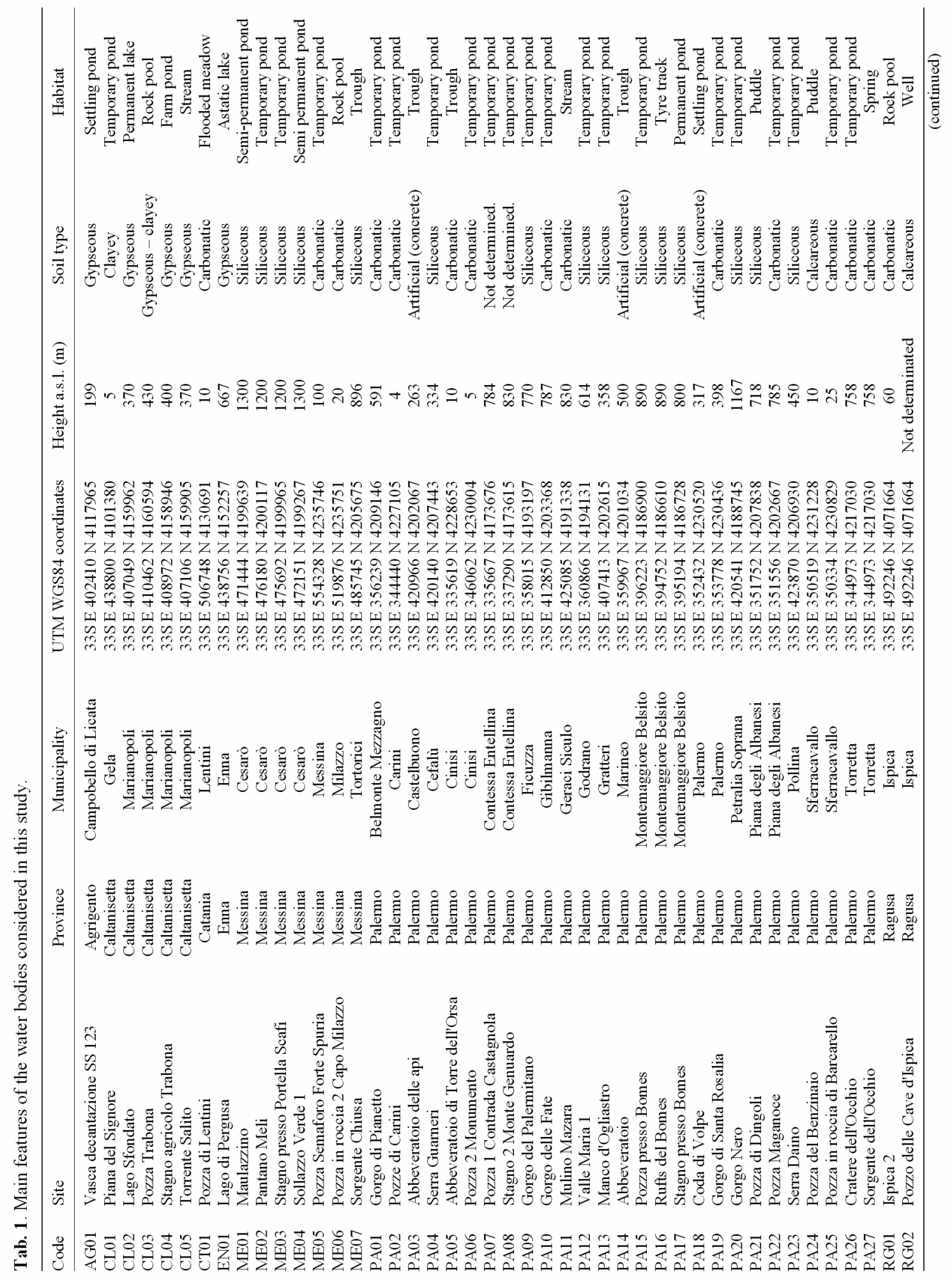




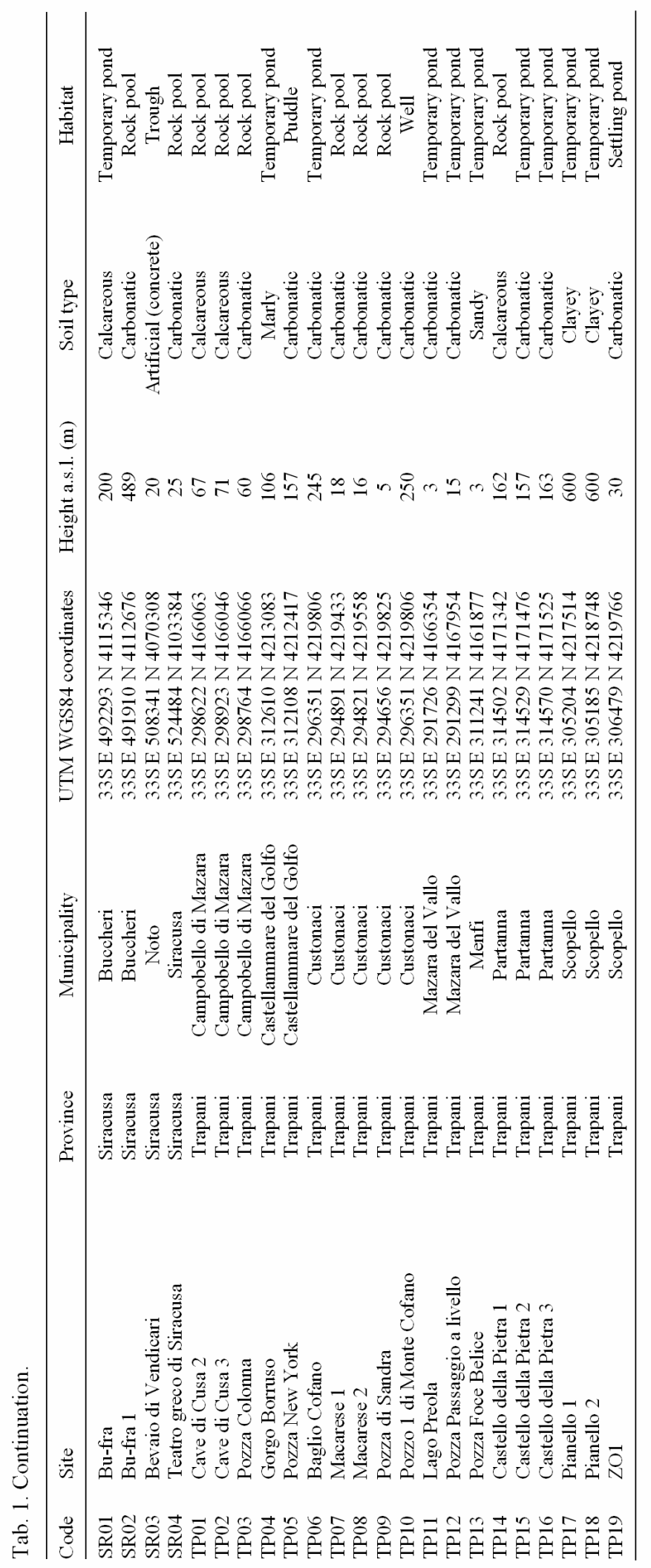


Tab. 2. List of identified ostracods and their occurrence in the study area (codes of sampling sites as in table 1 ; ${ }^{(1)}$ Eucypris cf. virens).

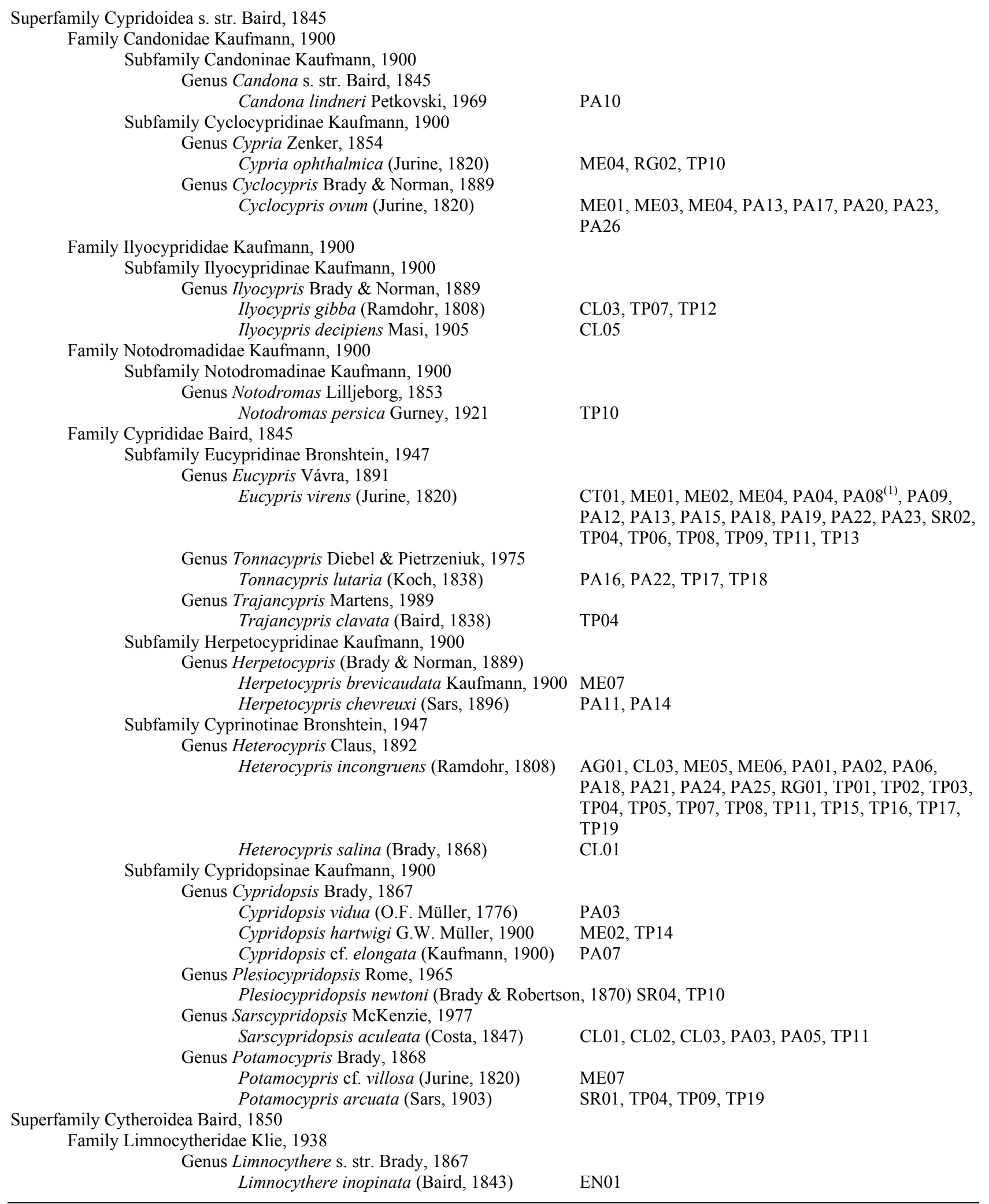


Ten taxa were recorded only in one sampling site: Candona lindneri, Ilyocypris decipiens, Notodromas persica, Trajancypris clavata, Herpetocypris brevicaudata, Heterocypris salina, Cypridopsis cf. elongata, Cypridopsis vidua, Potamocypris cf. villosa, and Limnocythere inopinata (Tab. 2). Although there were no particular patterns in the ostracod assemblages, it is interesting to see that in 4 sites (out of a total of 8 occurences) C. ovum occurred together with E. virens (Tab. 2), and that congeneric species were never found in the same sample. Among the more common species observed in the study area, only $C$. ovum showed a peculiar geographic distribution, being exclusively recorded in the north-central part of the island (provinces of Palermo and Messina) and from medium to high altitude (Tab. 2). Apart from the above mentioned distribution of $H$. incongruens, no apparent relationship between environmental variables and occurrence of ostracod species was observed. For example, $P$. arcuata was found at low altitudes (always below $200 \mathrm{~m}$ a.s.1.), but in waters with a wide $\mathrm{pH}$ range (between 6.32 and 9.95); S. aculeata was collected in contrasting habitat types (two temporary ponds, two troughs, a rock pool, and a permanent lake) characterized by a broad range of salinity, from relatively fresh $\left(2 \mathrm{mS} \mathrm{cm} \mathrm{cm}^{-1}\right.$ in PA03) to truly saline $\left(30.5 \mathrm{mS} \mathrm{cm}^{-1}\right.$ in CL01) waters.

From a comparison with the only two extensive surveys of ostracods carried out in inland waters of mainland Sicily (Riggio 1978; Margaritora et al. 1982), the present study led to the recognition of 10 new taxa; the record of $C$. lindneri is also new for the Italian fauna (Ghetti \& McKenzie 1981). On the other hand, two species reported in the previous investigations on Sicilian ostracods (Cyclocypris laevis and Cypris bispinosa), were not found in our samples (Tabs 2 and 3).

\section{DISCUSSION AND CONCLUSIONS}

In general, no clear relationship was observed between habitat features (altitude, size, water depth, hydroperiod) and the number of ostracod species. These results were somewhat expected, due to the overall prevalence of marginal, unpredictable aquatic ecosystems among the sampled sites: in fact, the wide physical and chemical fluctuations typical of these waters are likely to favour the establishment of generalist, highly tolerant species. Nevertheless, in few cases it was possible to relate the occurrence of ostracod species to a specific geographic area, habitat duration, or soil characteristics. For example, the distribution of Cyclocypris ovum seems to be consistent with the relatively temperate conditions of northern Sicily, while it has not been observed in the southern part of the island, which is more arid because it is directly affected by warm, dry air coming from northern Africa.

The present study significantly extends the previous data on the ostracod diversity in Sicily with the record of ten new taxa. Of interest is the occurrence of Candona lindneri, whose known distribution included central and eastern Europe, Slovenia, and Portugal (Meisch 2000). It has been found in a temporary pond (PA10), even though its usual habitats are waters connected to springs and the deep zone of lakes (Meisch 2000). So far, no endemic species of ostracods have been reported for Sicily, confirming a rather trivial faunal assemblage which consists of continental and circum-Mediterranean forms.

A total of ca 25 taxa are now known for Sicily, also including data from previous studies carried out in the mainland island (Tab. 3) or in circumsicilian islands, e.g. Heterocypris barbara from the Pelagian Archipelago (Bellavere et al. 2002). This list is certainly underestimated (e.g., the seasonality effect was not taken into account), so it is not meant to be an exact measure of the actual ostracod diversity of Sicily; regardless, the results of this study can reasonably be used to draw some preliminary conclusions.

Tab. 3. List of ostracods found in previous surveys carried out in water bodies of mainland Sicily (A: Riggio 1978; B: Margaritora et al. 1982). ${ }^{(1)}$ also Eucypris spp.

\begin{tabular}{lcc}
\hline & A & $\mathrm{B}$ \\
\hline Candona sp. & & $\mathrm{X}$ \\
Cyclocypris laevis (O.F. Müller 1776) & $\mathrm{X}$ & $\mathrm{X}$ \\
Cyclocypris ovum (Jurine 1820) & & $\mathrm{X}$ \\
Ilyocypris gibba (Ramdohr 1808) & $\mathrm{X}$ & \\
Ilyocypris decipiens Masi 1905 & & $\mathrm{X}$ \\
Cypris bispinosa Lucas 1849 & & $\mathrm{X}$ \\
Eucypris virens (Jurine 1820) & $\mathrm{X}$ \\
Herpetocypris chevreuxi (Sars 1896) & $\mathrm{X}$ \\
Heterocypris incongruens (Ramdohr1808) & $\mathrm{X}$ & $\mathrm{X}$ \\
Heterocypris salina (Brady 1868) & $\mathrm{X}$ & $\mathrm{X}$ \\
Plesiocypridopsis newtoni (Brady \& Robertson 1870) & & $\mathrm{X}$ \\
Sarscypridopsis aculeata (Costa 1847) & & $\mathrm{X}$ \\
Potamocypris villosa (Jurine 1820) & & $\mathrm{X}$ \\
Limnocythere inopinata (Baird 1843) & & \\
\hline
\end{tabular}

If one accepts the estimate that in Italy the valid species of non-marine ostracods are roughly one hundred (see discussion in Rossetti et al. 2004), then Sicily accounts for at least $25 \%$ of the entire country's ostracod diversity. Figures significantly vary when the same comparison is made with other freshwater crustacean groups. For example, about $50 \%$ of the Italian cladoceran species were identified in Sicily, where endemic taxa seem to be present as well (Marrone 2003; Marrone et al. 2005); also calanoid copepods are numerous and are mainly represented by north-African and eastMediterranean species (Marrone \& Naselli-Flores 2004, 2005). For both groups, species distribution is strictly related to environmental conditions. Conversely, Sicilian large branchiopod fauna is not well diversified, hosting widespread taxa and lacking of endemic species (Marrone \& Mura, unpublished data).

These marked differences lead to a puzzling picture when trying to interpret the distribution of the fresh- 
water crustacean fauna from a biogeographical point of view. To limit this discussion to ostracods, the species found in Sicily de facto form a mixture of Palaearctic and circum-Mediterranean forms, in which a clear distributional pattern cannot be identified. Only in a few cases was it possible to evaluate the relationships with Recent faunal assemblages of other Mediterranean islands. The most complete datasets are available for Corfu $\left(593 \mathrm{~km}^{2}\right)$ and the Balearic Archipelago (5040 $\mathrm{km}^{2}$ ). For the Ionian island, Stephanides (1948, 1960) listed 37 species (also including 3 brackish-marine forms), among them Physocypria kerkyrensis (endemic to Corfu) and Eucypris kerkyrensis (only known for Corfu and Hungary). A recent reviewed account by Zamora et al. (2005) reported 45 species for the Balearic Islands, four of them mostly occurring in brackish or saline waters, while one circumtropical species (Cypris decaryi) is probably of African origin. In both cases, there appears to be a higher ostracod diversity than in Sicily, especially if the island surface is taken into account. The differences become less evident when diversity is compared as the number of freshwater genera. The genus Limnocythere is exclusively found in Sicily, while two and five genera are restricted to Corfu and Balearic Islands, respectively (Tab. 4).

Tab. 4. Comparison between the freshwater ostracod genera reported for Sicily (this study), Corfu (Stephanides 1948, 1960) and Balearic Islands (Zamora et al. 2005). Genera whose occurrence is restricted to one of the considered geographic areas are shown in bold.

\begin{tabular}{|c|c|c|c|}
\hline Genus & Sicily & Corfu & Balearic Islands \\
\hline Darwinula & & & $\mathbf{X}$ \\
\hline Candona & $\mathrm{X}$ & $X$ & $X$ \\
\hline Pseudocandona & & & $\mathbf{X}$ \\
\hline Mixtacandona & & & $\mathbf{X}$ \\
\hline Candonopsis & & $\mathbf{X}$ & $\mathrm{X}$ \\
\hline Cyclocypris & $\mathrm{X}$ & $\mathrm{X}$ & $\mathrm{X}$ \\
\hline Cypria & $\mathrm{X}$ & $\mathrm{X}$ & $\mathrm{X}$ \\
\hline Physocypria & & $\mathrm{X}$ & \\
\hline Ilyocypris & $\mathrm{X}$ & $\mathrm{X}$ & $\mathrm{X}$ \\
\hline Notodromas & $\mathrm{X}$ & $\mathrm{X}$ & $\mathrm{X}$ \\
\hline Cypris & $\mathrm{X}$ & $\mathrm{X}$ & $\mathrm{X}$ \\
\hline Eucypris & $\mathrm{X}$ & $\mathrm{X}$ & $\mathrm{X}$ \\
\hline Tonnacypris & $\mathrm{X}$ & & $\mathrm{X}$ \\
\hline Trajancypris & $\mathrm{X}$ & & $\mathrm{X}$ \\
\hline Bradleycypris & & & $\mathbf{X}$ \\
\hline Herpetocypris & $\mathrm{X}$ & $\mathrm{X}$ & $\mathrm{X}$ \\
\hline Psychodromus & & $\mathbf{X}$ & \\
\hline Cypridopsis & $\mathrm{X}$ & $\mathrm{X}$ & $\mathrm{X}$ \\
\hline Potamocypris & $\mathrm{X}$ & $\mathrm{X}$ & $\mathrm{X}$ \\
\hline Heterocypris & $\mathrm{X}$ & $\mathrm{X}$ & $\mathrm{X}$ \\
\hline Plesiocypridopsis & $\mathrm{X}$ & $\mathrm{X}$ & $\mathrm{X}$ \\
\hline Sarscypridopsis & $\mathrm{X}$ & $\mathrm{X}$ & $\mathrm{X}$ \\
\hline Limnocythere & $\mathbf{X}$ & & \\
\hline Paralimnocythere & & & $\mathbf{X}$ \\
\hline Total number of genera & 16 & 16 & 21 \\
\hline
\end{tabular}

Only anecdotal or doubtful data exist for other islands in the central Mediterranean, namely Malta Archipelago, Corsica and Sardinia. For example, Anichini (1968), Tagliasacchi Masala \& Guareschi (1966) and Tagliasacchi Masala (1969) have described an astonishing number of new, endemic species in Sardinia and surrounding islands. Indeed, this anomaly is only apparent, since most (if not all) of those species must be synonymized with extant ones (Rossetti \& Martens 1996; Rossetti et al. 2004).

Also the current knowledge on ostracod distribution in northern Africa, mainly based on the classical works by Gurney (1909), Gauthier (e.g., 1928), Gauthier \& Brehm (1928) and more recently on a short account by Samraoui et al. (1998), is probably far from being exhaustive. For this reason, at this stage any further comparison would be purely speculative.

In conclusion, the role of Sicily as faunal bridge between circum-Mediterranean regions should be analysed in deeper detail in the case of freshwater ostracods. To test this hypothesis, a new, extensive sampling campaign is currently underway, which includes a larger numbers of water bodies in both mainland Sicily, its surrounding small islands, and in the MediterraneanSaharian transition zone.

\section{ACKNOWLEDGEMENTS}

Ostracods were partly identified during a visit of VP to KM, founded by the EU project Synthesys. Sampling activity by GR was supported by the EU project SEXASEX (MRTN-CT-2004-512492). Francesc Mezquita (València) provided updated data on the distribution of freshwater ostracods in the Balearic Islands. Julien Cillis (R.B.I.N.Sc., Brussels) offered technical assistance with the scanning electron micrographs. $\mathrm{Mr}$ Giuseppe Castelli (Palermo) is acknowledged for his help in sample collection. The authors thank the two referees for their valuable comments and suggestions.

\section{REFERENCES}

Anichini, G. 1968. Ostracodi delle piccole isole sarde meridionali. Rend. Sem. Fac. Scienze Univ. Cagliari, 38: 53-93.

Bellavere, C., G. Benassi, M. Calzolari, C. Meisch, K.G. McKenzie \& V. Rossi. 2002. Heterocypris (Crustacea: Ostracoda) from the Isole Pelagie (Sicily, Italy): the coexistence of different morphotypes. It. J. Zool., 69: 53-57.

Brullo, S., F. Scelsi, G. Siracusa \& G. Spampinato. 1996. Caratteristiche bioclimatiche della Sicilia. Giorn. Bot. Ital., 130: $177-185$.

Gauthier, H. 1928. Ostracodes et Cladocères de l'Afrique du Nord. Première note. Bull. Soc. Hist. nat. Afr. Nord, 19: $10-19$.

Gauthier, H. \& V. Brehm. 1928. Ostracodes et Cladocères de l'Algerie et de la Tunisie (3ème note). Bull. Soc. Hist. nat. Afr. Nord, 19: 114-121.

Ghetti, P.F. \& K. McKenzie. 1981. Ostracodi (Crustacea: Ostracoda). Guide per il riconoscimento delle specie animali delle acque interne italiane. Consiglio Nazionale delle Ricerche, Roma: 83 pp.

González Mozo, M.E., K. Martens \& A. Baltanás. 1996. A taxonomic revision of European Herpetocypris Brady and Norman, 1889 (Crustacea, Ostracoda). Bull. Inst. r. Sc. nat. Belg., Biol., 66: 93-132.

Gurney, R., 1909. On the freshwater Crustacea of Algeria and Tunisia. J. Royal Microsc. Soc., 443: 273-305. 
Margaritora, F.G., L. Mastrantuono, D. Crosetti \& F. Lombardi. 1982. Contributo allo studio della fauna ad entomostraci delle acque interne della Sicilia. Animalia, 9: 87102.

Marrone, F. 2003. On some cladocerans new to Sicily (southern Italy) (Crustacea Branchiopoda). Nat. Sicil., 27: 263270 .

Marrone, F. \& L. Naselli-Flores. 2004. First record and morphological features of Hemidiaptomus (Occidodiaptomus) ingens (Gurney, 1909) (Copepoda Calanoida) in Italy. J. Limnol., 63: 250-255.

Marrone, F. \& L. Naselli-Flores. 2005. First record of a representative of the subfamily Paradiaptominae (Copepoda Calanoida Diaptomidae) in Italy: Metadiaptomus chevreuxi (Guerne \& Richard, 1894). J. Limnol., 64: 89-92.

Marrone, F., R. Barone \& L. Naselli-Flores. 2005. Cladocera (Branchiopoda: Anomopoda, Ctenopoda and Onychopoda) from Sicilian inland waters: an updated inventory. Crustaceana, 78: 1025-1039.

Marrone, F., R. Barone \& L. Naselli-Flores. (2006). Ecological characterization and cladocerans, calanoid copepods and large branchiopods of temporary ponds in a Mediterranean island (Sicily, Southern Italy). Chem. Ecol.: (in press).

Meisch, C. 1984. Revision of the Recent Western Europe species of genus Potamocypris. Part I: Species with short swimming setae on the second antennae. Trav. Sc. Mus. Nat. Hist. Nat. Luxemb., 3: 1-55.

Meisch, C. 2000. Freshwater Ostracoda of Western and Central Europe. Spektrum Akademischer Verlag, Heidelberg, Berlin: 522 pp.

Naselli-Flores, L., R. Barone \& M. Zunino. 1998. Distribution patterns of freshwater zooplankton in Sicily (Italy). Verh. int. Ver. Limnol., 26: 1973-1980.

Received: October 2005

Accepted: January 2006
Riggio, S. 1978. L'ecologia del Fiume Oreto nel quadro della degradazione ambientale della zona di Palermo. Atti del secondo Convegno Siciliano di Ecologia, Noto, 23-25 October 1977: 175-273.

Rossetti, G. \& K. Martens. 1996. Redescription and morphological variability of Darwinula stevensoni (Brady \& Robertson, 1870) (Crustacea, Ostracoda). Bull. Inst. r. Sc. nat. Belg., Biol., 66: 73-92.

Rossetti, G., M. Bartoli \& K. Martens. 2004. Limnological characteristics and Recent ostracods (Crustacea, Ostracoda) of freshwater wetlands in the Parco Oglio Sud (Northern Italy). Ann. Limnol., 40: 329-341.

Samraoui, B., H. Segers, S. Maas S., D. Baribwegure \& H.J. Dumont. 1998. Rotifera, Cladocera, Copepoda and Ostracoda from coastal wetlands in northeast Algeria. Hydrobiologia, 386: 183-193.

Stephanides, T., 1948. A survey of the freshwater biology of Corfu and of certain other regions of Greece. Practika of the Hellenic Hydrobiological Institute, 2 (part 2): 1-263.

Stephanides, T., 1960. Some notes on the Entomostraca of Corfu, Greece, after an interval of 23 years. Praktika of the Hellenic Hydrobiological Institute, 7 (part 2): 3-10.

Tagliasacchi Masala, M.L. 1969. Descrizione di due nuove specie di Ostracodi della Sardegna: Eucypris caralitana ed Eucypris stagnalis (Morfologia, Ecologia e Biologia). Rend. Sem. Fac. Scienze Univ. Cagliari, 39: 1-26.

Tagliasacchi Masala, M.L. \& C. Guareschi. 1966. Studi biologici sulle acque termali della Sardegna. 1. Le sorgenti di Sardara. Arch. Zool. Ital., 51: 375-384.

Zamora, L., F. Mezquita \& J.Ll. Pretus. 2005. The nonmarine ostracod fauna of the Balearic Islands. Berliner paläobiol. Abh., 6: 133. 